\title{
Ferreira Gullar: \\ o fogo procura sua forma
}

VIVIANA BOSI ${ }^{I}$

A

TRAJETÓRIA de Ferreira Gullar (1930-2017), quer em sua obra poética, quer em seus estudos de estética, procurou responder às inquietações

culturais de nossa época. Desde os anos 1950, o poeta veio participando de debates políticos e artísticos.

Sua atuação se iniciou sob uma égide histórica dúplice: tratava-se tanto de um período de crise cultural pós-Segunda Guerra quanto de empuxo desenvolvimentista para o futuro. Enquanto na Europa e nos Estados Unidos ascendia a poética da "nova austeridade", que rejeitava o subjetivismo e as sublimações, no Brasil praticava-se o poema de feição elevada da geração de 1945, embora Cabral e alguns outros já acusassem direção antilírica. ${ }^{1}$

O poeta se propunha a destruir uma linguagem avaliada como carcomida em seu lirismo hedonista e alienado, ao mesmo tempo que valorizava fortemente a sociedade que se modernizava. Essa polaridade entre crise e construção reaparece ao longo de seu percurso de variadas maneiras. Em toda sua obra, desde o volume inaugural, Gullar reclama uma poesia presente, na carne das coisas, nos barulhos do dia, como se a linguagem não existisse antes do poema: "eu não podia mais me ater a normas prontas, eu tinha de descobrir no processo a forma do poema e esta é, enfim, a essência do livro $A$ luta corporal, em uma intensidade de procura que passa pela destruição, até chegar aos escombros do som e à 'sabedoria do corpo', à 'fala brotando em silêncio'” (Gullar, 1989, p.28).

De um lado, o retesamento entre expressividade e construção; de outro, a temática social; e ambas essas vertentes casadas em tensão: isso já resultaria em suficiente desafio para um poeta. Mas ele foi, ademais, um infatigável inquiridor da relação entre representação poética e passagem do tempo. De fato, interiorizou a substância do tempo na própria configuração do poema, como se a relação entre o instante da sensação e a vertigem cósmica precisasse ser evocada tanto sucessiva quanto simultaneamente para perfazer um ritmo.

Neste estudo, propomo-nos a perseguir dois aspectos de sua obra: ora o questionamento em relação à poesia, ora a interrogação sobre o tempo. ${ }^{2}$

\section{Primeiras manifestações}

O impulso por uma nova poesia afinava-se com o então jovem movimento concreto em meados dos anos 1950. Se bem que Gullar tenha composto, na época, alguns poemas visuais com aspectos semelhantes ao da poesia concreta, recusando o discursivo em nome de uma linguagem mais substantiva, logo se 
interessou pela arte neoconcreta, que se encaminhava para criar formas plásticas que rompessem com modelos anteriores de pintura e escultura. No "Manifesto da primeira exposição neoconcreta" (Museu de Arte Moderna, MAM-RJ, 1959, republicado em Gullar, 2007), uma das críticas que o poeta endereçava ao concretismo tinha por alvo o que julgava ser uma "perigosa exacerbação racionalista", pois desconfiava dos "limites impostos pela teoria". Propunha, em contrapartida, o afastamento de aspectos cientificistas, matemáticos, mecânicos, e a aproximação do organismo vivo, em uma arte relacionada ao corpo e à experiência. Embora concordasse com os concretos quanto ao repúdio da "sintaxe unidirecional", apoiava, junto aos outros artistas que subscreviam o "Manifesto neoconcreto", a volta ao "verbo", que considerava mais expressivo. Sugeria-se o conceito de um espectador participante nessas primeiras experiências com poemas-objetos, os quais necessitam da ação interativa de um interlocutor para desvelar-se como significado pleno.

Apesar de guardarem alguns pontos comuns com a proposta concreta, tanto na poesia quanto nas artes plásticas, ${ }^{3}$ havia também fortes desavenças. Como bem concluiu Ronaldo Brito (1985; 1999), o neoconcretismo foi o ápice do ideal construtivista, último rebento e já a semente de sua desagregação, porque existia ali uma crise exacerbada que reconhecemos traduzida desde $A$ luta corporal (1954), anterior ainda a toda essa formulação teórica. Por fim, as próprias cisões internas, intimamente articuladas à situação histórica, levaram alguns artistas ao engajamento político e a experiências de performance.

Cito Gullar (2007 [1959], p. 98-9) em trecho da "Teoria do não-objeto" em que tal inquietude materializa-se plenamente e no qual explicita suas diferenças, já se antevendo consequências posteriores:

Também o poeta busca a experiência primeira do mundo, também ele trabalha no limite da linguagem poética.

$\mathrm{Na}$ época moderna, vimos a destruição das formas fixas de estrofe, de verso, para chegar-se ao verso livre. Mas, depois, o verso livre também tornou-se um instrumento estereotipado: rebentou-se a sintaxe e chegou-se à palavra como elemento primeiro. Da mesma maneira que a cor libertou-se da pintura, a palavra libertou-se da poesia. O poeta tem a palavra, mas já não tem um quadro estético preestabelecido onde colocá-la habilmente. Ele se defronta com ela desarmado, sem nenhuma possibilidade definida mas com todas as possibilidades indefinidas. O que importa não é fazer um poema - nem mesmo fazer um não-objeto - mas revelar o quanto de mundo se deposita na palavra.

A consciência do hiato irresolúvel entre mundo e palavra vai permanecer constante em sua obra, e conservará aguda conexão com a interrogação sobre a matéria da vida (imersa no tempo que passa) e sua relação com a poesia, dilema para o qual o poeta buscará diferentes formulações. Amigo de Mário Pedrosa, que muito o influenciou, todo o seu empenho teórico para compreender as inovações de Lygia Clark e Hélio Oiticica, as quais compartilhava naquele período, segue na direção de imaginar uma arte que superasse a representação e criasse o 
seu próprio espaço: o "não-objeto" deveria ser "pura significação”, "imanente à sua própria forma" - uma "presentação" de algo anterior aos nomes já classificados, como lemos acima na "Teoria do não-objeto" (2007, p.94ss).

A polarização, nesse caso, dá-se entre o tempo vivo de criação do poema e sua posterior solidificação como parte da cultura (que ele afirma e nega, gerando uma dimensão própria). Esse conflito deveria transparecer no interior da obra, uma vez que, segundo reafirmava, aliás em consonância com o ethos construtivista, "A arte não é uma atividade de segundo grau mas um ato primeiro que muda o mundo" (Gullar, 2007 [1961], p.110, “O tempo e a obra”).

Naquele momento, Gullar ensaiava formas poéticas vizinhas às artes plásticas, tais como o "Poema enterrado" ou os "Poemas espaciais". E quando, depois de passar pela fase mais politicamente engajada, compõe, nos anos 1970, uma poesia mais próxima do que viria a ser sua trajetória até recentemente, voltamos a encontrar muito das preocupações manifestadas em seus primeiros textos.

\section{Tempo e poesia}

A fortuna crítica de Ferreira Gullar sempre realçou a questão do tempo em sua poesia. Sem pretender discorrer sobre todas as complexas reflexões acerca do tema, focalizo, sumariamente, algumas ponderações que se confirmam em quatro ensaístas, à guisa de alicerce fundamental para o que me proponho a acrescentar.

No estudo longo mais antigo sobre o poeta, João Luiz Lafetá (1982) logo percebeu que a consciência da "passagem desagregadora" do tempo, que conduz para a destruição a beleza fugaz dos viventes, era um motivo axial de Gullar desde seu primeiro livro: "o canto, coisa viva, em que se trabalha, é inquietude, luta contra a morte" (Lafetá, 1982, p.74), compreendia o crítico. Mas, nem sempre a linguagem pode resistir ao curso de deterioração das coisas. Por isso, o fogo aparece constantemente como imagem do ardente consumir-se de tudo, até da própria poesia. Haveria nos seres uma cintilação que logo se perde, inútil e solitária. Desde A luta corporal (1954), ao desencavar e depois voltar a enterrar o cadáver do anjo, "o poeta recusa o mito da eternidade, firma-se na constatação do perecimento de tudo" (ibidem, p.81).

A seguir, o ensaio de Alfredo Bosi sobre Gullar encarecia traços análogos, acrescentando a percepção de que

A matriz do seu mundo poético é a Cidade da infância e da adolescência, aquela São Luís mítica e realíssima onde o Sol irradia por um céu cruelmente azul e arde como um fogo que é a própria figura do Tempo. A chama calcina como as horas. O fogo queima, se rápido, ou, se lento, faz o germe explodir, a polpa adoçar até o mel e, obsessão fecunda, leveda a natureza até o apodrecimento, a náusea, a inexorável combustão dos seus mais ocultos tecidos. [...] No poema de Ferreira Gullar uma intimidade febril une o sol e a morte, e esta, repito, me parece ser a forma imaginária com que o poeta diz o seu sentimento do Tempo. (Bosi, 1983, p.7-8) 
Alcides Villaça também refletia:

As imagens da iluminação e as do escuro constituem pois um campo simbólico geral da luta que se trava entre o impulso lírico e a consciência da sua impossibilidade, tudo desembocando na ironia mortal que conduz à pulverização do discurso. $\mathrm{O}$ antagonista maior, quase absoluto, é o Tempo, menos histórico que fenomênico, ação material da natureza sedutora mas ilusória, fátua e fatal. A tarefa dessa poesia está em perfurar a superfície enganosa para encontrar, no cerne de cada coisa ou ser, o que lhe é essencial: "um contínuo negar-se". Assim, o azul do céu é "mais que azul": "ele é o nosso sucessivo morrer". (Villaça, 1998, p.93)

Por fim, o sugestivo ensaio de Leonardo Martinelli (1997) procurava explorar o estiramento entre o tempo que passa versus a forma que perdura no próprio tempo do poema, cuja linguagem é destruída, fraturada e conspurcada em nome da ânsia de existir. $\mathrm{O}$ "incêndio" retrata a figura da impermanênciada representação, pois as coisas consumidas pelo fogo só podem brilhar no segundo antes do vórtice implacável que as corrói, visto que as palavras não as apanham de fato, apenas as alumiam vivaz e fugazmente.

Num dos poemas antigos em que mais se destaca a composição aparentemente harmônica entre o existir passageiro (mas concreto e sólido) e o fogo do tempo que consome a vida selvagemente, "Frutas" ( $O$ vil metal, 1960, em Poesia completa, teatro e prosa - Gullar, 2008, p.65), contrapunham-se o universo doméstico, a sustentar-se no presente aparentemente calmo de uma "mesa no domingo", e em oposição, o "mar atrás", como cena pictórica instável devido às chamas que vem devorar por dentro e por fora o pequeno arranjo humano:

Sobre a mesa no domingo

(o mar atrás)

duas maçãs e oito bananas num prato de louça

São duas manchas vermelhas e uma faixa amarela

com pintas de verde selvagem:

uma fogueira sólida

acesa no centro do dia.

O fogo é escuro e não cabe hoje nas frutas:

chamas,

as chamas do que está pronto e alimenta.

Um tipo de natureza morta (still life) em que a vibração opera de dentro e de fora da matéria." "Que não seja imortal posto que é chama/ mas que seja infinito enquanto dure" - fórmula lapidar de Vinicius de Moraes para definir tanto a emoção poética quanto a amorosa - parece uma tentativa de pensar o lugar da poesia na vida um pouco diferente dos anteriores "Peras" ou "Galo galo" (constantes em $A$ luta corporal, 1954), nos quais os seres existiam para a morte solitária e sem redenção, em meio à indiferença do seu meio. Aqui, as frutas ardem no fulgor intenso de um instante, mas ele é belo e vale por si mesmo. Ao 
invés de apodrecer inutilmente, elas trazem dentro de si energia nutritiva. Por dentro e por trás da aparência "sólida", tudo se desequilibra em combustão - o escuro perpassa a luz das cores que se autoconsomem.

A qualificação do tempo como ser vivo com corpo de luz, que resiste a morrer, comparece desde os começos juvenis de sua poesia. Os nomes dos meses (dezembro, fevereiro, março, setembro) caracterizam-nos como deidades animalizadas, potências que presidem as deambulações pelas ruas, em meio às vitrinas, pontos de ônibus, jardins - qual aviões ou torpedos suicidas que se abatem sobre a cidade, sinais da passagem intensa do tempo, entreouvida junto aos ruídos da bulha cotidiana:

Este fevereiro azul como a chama da paixão nascido com a morte certa com prevista duração

deflagra suas manhãs sobre as montanhas e o mar com o desatino de tudo que está para se acabar.

(primeiras duas estrofes de "Verão", Dentro da noite veloz, 1962-1975 - Gullar, 2008, p.159)

O "sôfrego pulsar" do coração diário confere aos poemas um ritmo por vezes enumerativo e desconjuntado, aos trancos, como se a multidão dos homens e mulheres o atravessasse em diferentes compassos enquanto certa cadência se mantém, de acordo com rotações variadas, lentas ou aceleradas, formando um painel complexo que inclui insetos e estrelas. "Muitos/ muitos dias há num dia só/ porque as coisas mesmas/ os compõem/ com sua carne (ou ferro/ que nome tenha essa/ matéria-tempo/ suja ou/ não)" - a matéria-tempo se move de modo "sinfônico" e "simultâneo", como já notou a crítica, ou "vertiginosamente devagar", tal como se desfazem frutas e homens:

Sou um homem comum

de carne e de memória

de osso e esquecimento.

Ando a pé, de ônibus, de táxi, de avião

e a vida sopra dentro de mim

pânica

feito a chama de um maçarico

e pode

subitamente

cessar.

(primeira estrofe de "Homem comum", Dentro da noite veloz, 1962-1975 - ibidem, p.153) 
Por vezes, a revolta poética assume viés político de denúncia, como se reconhece em tantos versos desse livro bem representativo dos anos 1960. Mas pode ser brusca demais a exteriorização desse rechaço do "mero" verbo. No sobejamente conhecido "A bomba suja", Gullar emula a "Antiode" cabralina para de novo pedir licença e colocar no poema o que nele não caberia, o que reputa como verdadeiramente "real": "Introduzo na poesia/ a palavra diarreia" [...] "Quem fala em flor não diz tudo./ Quem me fala em dor diz demais./ O poeta se torna mudo/ sem as palavras reais". E, mais adiante no livro, insiste: "O preço do feijão/ não cabe no poema" [...] "O poema, senhores/ não fede/ nem cheira" ("Não há vagas"). O seu empenho em mobiliar o espaço do verso com materiais da atualidade e mesmo com os sentidos corporais, vai até o ponto de torná-lo jornalístico e literal ao máximo, como em "Poema brasileiro".

Um dos desafios que percorrema arte da época é o anseio por participação social e a crença de que o artista teria uma função conscientizadora. Ao mesmo tempo, há um sentimento de impotência e de sublevação tanto dos próprios artistas quanto da crítica contra os objetos artísticos, declarados insuficientes para sustentar projeto tão grandioso. $\mathrm{O}$ enfrentamento com a dura realidade da vida do povo brasileiro, ao lado de um sentimento de urgência impeliram Gullar à simplificação da linguagem poética e até ao didatismo, como se o poema devesse cumprir a função de iluminar e acender imediatamente o tempo presente mas fosse, entretanto, insatisfatório para cumprir tal exigência. Essa é uma contradição que a poesia de Gullar encarou de variadas maneiras - desde A luta corporal (1954), e que podemos reter em mente.

Em vez de pressupormos uma ruptura brusca entre o momento neoconcreto e o posterior engajamento, poderíamos localizar certa continuidade no impulso ambicioso de armar a poesia com potencial revolucionário, seja nas premissas daqueles primeiros manifestos, seja nas pesquisas com as formas do cordel e de "agitprop".

Mas o tom podia soar um tanto empostado, desequilibrando-se na direção do discursivo. "Essa não coincidência entre o momento lírico e o plano histórico-social é marca aguda da poesia moderna", pondera Villaça (1984, p.179), referindo-se à procura do poeta por uma forma de alcançar traduzibilidade ou ponte de participação entre sujeito, de um lado, e mundo de coisas e homens, de outro.

Aos poucos, ao longo dos anos 1960 e começos dos 1970, a poesia de Gullar foi superando essa dificuldade. Escreveu poemas a respeito da guerra do Vietnã e da morte de Guevara (já em 1968), nos quais se pressente a ampliação de horizontes não apenas geopolíticos, mas igualmente da imaginação e do ritmo.

Escolho um poema breve, no qual se notam tanto a desafinação irresolvida quanto o casamento entre interior e exterior, quando o poeta intenta falar de sua experiência como fugitivo clandestino depois do golpe militar: 
Madrugada

Do fundo de meu quarto, do fundo

de meu corpo

clandestino

ouço (não vejo) ouço

crescer no osso e no músculo da noite

a noite

a noite ocidental obscenamente acesa

sobre meu país dividido em classes

(Dentro da noite veloz, 1962-1975 - Gullar, 2008, p.193-4)

As reiterações para acentuar o fundo, o escondido, o que punge no osso (a noite, a noite, a noite... três vezes seguidas) - não separado intelectualmente pela visão, mas gravado dentro de si (ouço osso), no músculo (do eu lírico? da noite?), palavra também noturna, são a penetração no próprio corpo da verdade interdita, do que resume essas trevas do país (e do ocidente inteiro) iluminado por uma claridade falseadora que cicia (ocidental obscenamente acesa) - luz que se projeta sobre a divisão de classes - força externa que exibe claramente o vergonhoso da atomização e da desigualdade do que deveria ser um coletivo justo. A escuridão que cresce, amalgamando sujeito e mundo, torna-se subitamente imensa e opressiva, como se o eu escondido no "fundo de meu corpo", na intimidade sombria do quarto, fosse projetado para a amplitude da consciência do país onde se efetiva a disparidade social. Embora o título seja "Madrugada", não parece remeter a uma alvissareira aurora. Pelo contrário, o dia vindouro impõe ao poeta a lucidez desencantada do real.

Nesse poema já se delineia um traço que irá percorrer toda sua obra: para além da visão (tipicamente cabralina...), Gullar mergulhará nas sensações - táteis, olfativas - para alcançar e dar a sentir esse mundo tangível anterior a todo conceito, anterior mesmo à palavra, obsessão que o acompanhará até seus últimos livros. O corpo do mundo que ele percute e faz vibrar propiciará a realização do seu verdadeiro projeto de escrita poética com alcance social.

Os dois últimos versos de "Madrugada" são, porém, fieis ao antilirismo de um reconhecimento indignado, em que quase não há transfiguração e o enunciado se dá ao rés do chão. É comum em seus poemas dos anos 1960 um começo mais autorreflexivo, seguido por um desenlace abrupto que hoje nos soa um tanto altissonante, descaindo em retórica. Perde-se a mediação imagética e sonora, assim como a particularidade concreta, expondo ideais de modo exterior. Villaça (1998, p.99) considera essa passagem para o conceitual um despencar para o emblema explicitamente alegorizante. Concordo, mas matizo, pois, conforme o crítico comenta em outras passagens, também nesses versos ocorre um forte movimento de interiorização por meio do qual tanto o corpo do sujeito 
quanto o da linguagem se projetam no poema. Naqueles anos, a ira da denúncia e o desejo utópico mobilizavam de tal modo a arte que ela renunciava por vezes à mediação do trabalho formal para aproximar-se da "universal reportagem", desagregando-se no limite da antiarte, tal como se verifica, por exemplo, em duas obras de Oiticica: o estandarte ("seja marginal seja herói"), semelhante aos dois versos finais do poema "Agosto 1964", de Gullar ("um poema/ uma bandeira"), e o bólide em homenagem a Cara de cavalo (o amigo morto pela polícia), que se parece sobretudo com uma ação ritual.

Torna-se claro o desacordo exasperante entre o aqui e agora irremissível da existência diária em curso e as palavras arranjadas artisticamente no poema. No entanto, ainda assim, Gullar (2008, p.269) exprimirá a insatisfação... em palavras... mesmo que ao ponto de desconfiar totalmente delas, como se verifica, dez anos mais tarde em "O poço dos Medeiros" (Na vertigem do dia, 1975-1980), no qual declara: "Não quero a poesia, o capricho/ do poema: quero/ reaver a manhã que virou lixo". O poema, porque simulacro da vida, é tomado como mentira. Novamente, o autor se revoltará contra a poesia como obra morta, e advogará em favor da sensação, do imediato: embora consciente do intervalo entre presença e discurso, ele exige que a palavra incorpore uma voz atuante.

"A poesia é o presente", assegura o eu lírico em "No corpo" (Dentro da noite veloz, 1962-1975), quando desaprova o estatuto de obra perene do poema: "Poesia - deter a vida com palavras?/ Não - libertá-la,/ fazê-la voz e fogo em nossa voz. Po-/ esia - falar/ o dia ("A poesia", ibidem). Ecoam os timbres do corpo, onipresente no Poema sujo ou em tantos outros versos daqueles anos.

Grifamos essa impaciente e contraditória negação da poesia em "Arte poética" ("Não quero morrer não quero/ apodrecer no poema"), na qual toda a disposição dos versos divide-os entre o universo ígneo, vital, e a tentativa de embalsamamento que seria a palavra escrita. Se pudéssemos sintetizar o vórtice que a arte do período exibe em uma pequena estética da dessublimação e da gana de retomar a vida, leríamos como um manifesto este poema paradoxal:

Não quero morrer não quero

apodrecer no poema

que o cadáver de minhas tardes

não venha feder em tua manhã feliz

e o lume

que tua boca acenda acaso das palavras

- ainda que nascido da morte -

some-se

aos outros fogos do dia

aos barulhos da casa e da avenida

no presente veloz 
Nada que se pareça

a pássaro empalhado múmia

de flor

dentro do livro

e o que da noite volte

volte em chamas

ou em chaga

vertiginosamente como o jasmim

que num lampejo só

ilumina a cidade inteira

(Na vertigem do dia, 1975-1980 - Gullar, 2008, p.294-5)

Tanto a primeira como a segunda estrofes erigem-se sobre imagens que fortemente se contrastam, distinguindo a morte, noturna e rígida, do fogo diário, instantâneo, veloz. O movimento rotatório em espiral dos versos da última parte do poema bem representa a intensidade da aspiração de encarnar-se na duração do tempo horizontal da vida, que afinal acelera-se em ressonâncias as quais mimetizam a "vertigem" do instante. Com isso, tenta furtar-se à mumificação da arte empalhada no museu. O ideal de uma arte semelhante à chama, que se consome sem se fixar, mas que, no momento em que fulge, ilumina a cidade sem deixar peso ou rastro, acompanha o poeta sempre, como voltagem que não cede, recusando-se, na forma, a abandonar a construção do poema, ao mesmo tempo em que, no conteúdo, incita o elogio do instante.

Em rebelião contra a forma estática, aspirando a cadavérica, da arte autônoma, o poema proclama o movimento do fogo, em sua voraz vitalidade, como modelo de duração e intensidade. A fisionomia deste e de tantos outros poemas corrobora o impulso para o perpétuo deslocamento, quando os versos se desalinham na página, desarranjando a estaticidade dos recuos usuais. ${ }^{5}$

Até mesmo em poemas claramente "metapoéticos", como "O espelho do guarda-roupa" ( Na vertigem do dia), o eu lírico evita mineralizar as palavras, nunca retidas em conserva. O próprio espelho é água e estilhaço, enquanto "por trás do meu rosto/o dia/ bracejava seus ramos verdes / sua iluminada primavera". Tudo se agita e cresce: mesmo quando dormindo, o poeta "é como um acrobata/ estendido sobre um relâmpago".A ventania, o marulho do mar são alguns dos rumores inquietos que vêm desequilibrar a figuração no poema. O problema da representação imobilizadora é que, embora reflita “a paisagem”, não consegue preservar o movimento ruidoso da vida: "o vento nas copas / o ladrar dos cães / a conversa na sala// barulhos/sem os quais/ não haveria tardes nem manhãs". Nem o próprio sujeito petrifica a imagem de si próprio enquanto o tempo passa, preenchido por pedacinhos de tempos menores, que podem ser particularizados e nomeados pela experiência mais cotidiana. 
Em relação ao Poema sujo (1976), porém, concluía Lafetá (1982), firma-se um movimento que já vinha crescendo desde livros anteriores, quando a memória recupera a infância, ao mesmo tempo em que imerge nas velocidades plurais de tantos dias, objetos, pessoas, que circulam lado a lado, juntas ou distantes. De forma similar, Bosi $(2003$, p. 175) acentua a "simultaneidade dos múltiplos modos de existir da vida íntima e pública de São Luís".

A consciência da finitude, se implica desconfiança em relação à durabilidade da vida, torna preciosos os pequenos caroços narrativos associados à memória dos amigos e da infância, como se fossem espessamentos que permanecem, pouco antes de serem tragados pelo aflorar incessante de um novo presente.

Aduziríamos que os segmentos narrativos fragmentariamente espalhados ao longo do Poema sujo reafirmam a noção de sujeito, tão recalcada pela impessoalidade associada à vanguarda concreta. Trata-se de uma biografia mutilada, exposta através de episódios epifânicos, mas que ainda assim buscam coesão à volta da experiência de um indivíduo.

O poema é costurado com esquecimentos e núcleos de lembrança, como se o sujeito tivesse sido lacerado na sua própria história, e agora, ao tentar se reconstituir, não pudesse responder por si mesmo de forma completa, tendo se convertido em um grande amontoado, ou enumeração de partes que não se totalizam. A superposição de tempos e espaços o ajudou a restaurar um passado dissonante, movendo a esperança ardente do futuro.

No Poema sujo reconhecemos, por conseguinte, um procedimento que reaparecerá muitas vezes em sua obra. O sujeito lírico começa por apresentar uma sensação (um cheiro de hortelã, de jasmim, de esgoto, de mangue - ou o ritmo do trem - ou uma cor da água), semelhante a uma fulguração da memória involuntária. O som "turvo" precede imagem e sentido, e depois os rompantes de lembrança e esquecimento, mesclados, emergem como gênese criador, de um fundo perdido, em colherinhas de chá tomadas repetidas vezes. E então um núcleo é constituído à volta daquele instante fugidio, quase irrepresentável. Os versos se expandem como constelações de cenas. As interrupções parecem mais fiéis justamente ao que estava ocorrendo no Brasil: a discrepância entre a cidade provinciana de São Luís, o avião que passa, a lembrança dos índios inscrita nos pássaros, a pobreza das casas da favela, a industrialização, o banimento político... toda aquela mescla muito rica que desponta em surtos descontínuos. No final, o poeta tenta encaixar os tempos de forma metonímica e serial, à maneira de João Cabral. Busca, assim, racionalizar aquele ir e vir entre passado e presente.

Opera-se um envolvimento visceral com a dimensão coletiva social, que foi processada substancialmente e passou a entrar de igual para igual na linguagem lírica, porque esta se alargou para recebê-la. O exílio levou o poeta a expressar uma subjetividade solitária, não obstante, por meio do afeto e da memória, agora sim múltipla e solidária. O "adensamento" e a "dimensão coral" (Bosi, 1983 , p.10) provieram da autoescavação, através da qual alcançou as diversas 
vozes contidas no fundo de si, como se pode constatar em um trecho do grande poema:

Não sei de que tecido é feita minha carne e essa vertigem que me arrasta por avenidas e vaginas entre cheiros de gás e mijo a me consumir como um facho-corpo sem chama, ou dentro de um ônibus

ou dentro de um Boeing 707 acima do Atlântico acima do arco-íris

perfeitamente fora

do rigor cronológico

sonhando

Garfos enferrujados facas cegas cadeiras furadas mesas gastas balcões de quitanda pedras da Rua da Alegria beirais de casas cobertos de limo muros de musgos palavras ditas à mesa do jantar,

voais comigo

sobre continentes e mares

E também rastejais comigo

pelos túneis das noites clandestinas

sob o céu constelado do país

entre fulgor e lepra

debaixo de lençóis de lama e de terror

vos esgueirais comigo, mesas velhas,

armários obsoletos gavetas perfumadas de passado,

dobrais comigo as esquinas do susto

e esperais esperais

que o dia venha

E depois de tanto, que importa um nome?

Te cubro de flor, menina, e te dou todos os nomes do mundo:

te chamo aurora

te chamo água

te descubro nas pedras coloridas nas artistas de cinema

nas aparições do sonho

(Poema sujo, 1976 - Gullar, 2008, p.207-8)

De um lado, o sujeito se dilui entre os objetos velhos da memória que o compõe, junto a homens e bichos; de outro, se expande ao deslocar-se acima do espaço terreno, voando, ou abaixo da vida comum, no subterrâneo clandestino, pelos esgotos secretos onde flui o recalcado, perseguido, proibido. Ele está fora do espaço urbano, e além do tempo cronológico da vida comum, carregando consigo os restos do passado, esfarrapados e gastos. No meio da noite, da lepra, da lama, do terror e do susto, escondido por armários, gavetas, esquinas, lençóis... dobras que o protegem enquanto rasteja e se esgueira por túneis... Em 
vez de caminhar na cidade, pedestre entre coisas e homens, como fazia antes (em vários poemas dos anos 1960), arrasta-se por baixo ou sobrevoa oniricamente o Atlântico acima do arco-íris, e incorpora objetos e pessoas ausentes. $\mathrm{O}$ passado perdido e reconquistado torna-se sua identidade. As coisas e pessoas esquecidas, quebradas ou mortas, voltam a existir por intermédio de seu corpo e de sua mente, perpassadas por um vigoroso afeto. Assim como o espaço e o tempo são ampliados por viagens e lembranças, o anseio veemente pelo futuro, pelo clarear do dia, foi subjetivado graças a essa mediação da distância física e psíquica, que, se conduziu a um afastamento, permitiu uma projeção intensa do desejo. Aparecem fachos de luz e grandes espaços - a nova manhã: "esperais esperais/que o dia venha". O amor transfigurado pelo que nasce: "Te cubro de flor, menina" - menina que se chama aurora, água, pedra colorida, artista de cinema, e finalmente, aparição de sonho... quem seria, então, esta que é o ápice de todos os devaneios políticos e amorosos? A própria plenitude do tempo?

A pluralidade que o poema convoca, fazendo irromper o menino e o adolescente dentro do homem, junto às muitas vozes do seu passado, seja em breves sequências narrativas, seja pela imersão nas sensações vivenciadas (fiapos de cor, luz, cheiros que se entramam dentro de si, bichos e corpos que nascem da terra), transforma-se numa multiplicidade de pontos de vista. A perspectiva do eu lírico aflora, mas não é exclusiva: diversidade e vertigem avultam no "poema sinfônico" (Villaça, 2008, p.xlvss), uma vez que seu corpo é uma galáxia em expansão inclusiva.

"Não sei de que tecido é feita minha carne"...

"E depois de tanto,/ que importa um nome?"

O próprio processo de elaboração, concebido como montagem e colagem de fragmentos aparentemente independentes, busca engajar-se profundamente no real: "a identificação com os outros homens surge como que nascendo do íntimo, espontânea, e a sentimos como natural" (Lafetá, 2004, p.207) e não se reduz a sistemas ideológicos previamente arranjados - na vida e na poesia. Tanto que o poema começa antes das palavras e da constituição do sujeito, pois desde o início está mergulhado no mundo sujo, turvo. (Nisso ele deve muito a "O cão sem plumas": o mergulho no mangue da matéria mais inconsciente - um lugar do espírito que se confunde com o inumano). Não há mais arestas entre o corpo no fundo do quarto noturno e a vida social: os objetos, o passado pessoal e histórico, as pessoas, o país, tudo entra na roda gigante do poema, que absorve, deglute e expele insetos, estrelas, roupas velhas, cheiro de sabão, palafitas, pai e mãe, o soldado, a vizinha, o comerciante, a professora, o capim, a sucata do terreno baldio...

Naquele período, o poeta adquiriu consciência do eu como processo desdobrado em vários tempos e lugares, tomando parte no mundo, o qual não é mais estanque: a luta é comum, para vir a ser, para constituir-se. Enquanto nos romances do cordel e na poesia engajada dos anos 1960 a voz parecia alheia, 
os poemas contemporâneos ao Poema sujo, na década seguinte, "não abdicam da interioridade problemática, registrada em seu esforço para o devir" (Villaça, 1984, p.115). Enfim, Gullar alcança uma "aliança verdadeiramente nupcial de sujeito e objeto, que só se realiza quando a alma consegue objetivar-se na mesma medida em que a História consegue subjetivar-se", sustenta Bosi (1983, p.9), a respeito da sua poesia a partir de então.

O seu corpo ecumênico corresponde afinal à cidade. Ambos se entremeiam, na ausência recordada, mais ativa do que antes, quando nela caminhava de fato. Assim, a voz poética se amplia, polifônica, em associação com diferentes vidas e objetos em seus ritmos próprios, de durações desiguais mas simultâneas.

Torna-se contínua a percepção de que o tempo passa de modo irremissível, amoldado no poema a imagens de fogo, chama, clarão do instante. Não há distância e calma para o diamante polido quando a poesia quer tratar de sangue, de corpos que se amam ou se ferem e podem morrer. Gullar, em mais de um depoimento sobre o Poema sujo, falava da premência com que desejava "vomitar" a "matéria bruta". ${ }^{6}$ Tema reiterado em muitos e muitos versos que confessam a precariedade humana assim como a da poesia, no mesmo diapasão.

Questão que continuou a acompanhá-lo, como se lê no poema "Desastre": "Ah, quem me dera o poema podre" - "Um poema/ como um desastre em curso." (Barulhos, 1987). O retesamento entre a permanência da matéria e a instabilidade do tempo, que ceifa tanto as frutas quanto os homens, faz-se paralelo ao anseio dramático de gerar vida no poema, como se este fosse uma usina de energia que pudesse acender uma flama na realidade.

O poema quer ser "uma luz do chão", o mais prosaico e menos "literário" possível, afirma Gullar, numa entrevista: "É esse frescor da experiência vital, primeira, que pretendo captar e expressar". Assim, tanto em Barulhos (1987) quanto em Muitas vozes (1999) repropõe sua pregressa teoria do não-objeto, batizando um poema de "Não-coisa" e nele recolocando algumas das perguntas que o assombram desde sempre. Começa por dizer que não cabe no discurso o sabor, o perfume, o odor, o barulho, do mundo, mas que o poema tenta "incutir na linguagem/ densidade de coisa", ainda que consciente da impossibilidade. O poema é, também, a voz dos outros, e não mais uma obra estanque e isolada (como acreditava quando publicou "Galo, galo" em 1954) Termina assim:

Toda coisa tem peso:

Uma noite em seu centro.

O poema é uma coisa

Que não tem nada dentro

A não ser o ressoar

De uma imprecisa voz

Que não quer se apagar

- essa voz somos nós. 
Assim, as "muitas vozes" podem afinal habitar o verso, sacudido pelo ruído das ruas, do verão que envolve a cidade e o homem, os quais a língua intenta incorporar ao poema.

Após haver passado por dicotomias radicais entre a potência lírica e o prosaísmo didático do discurso engajado, Gullar atingiu, na poesia, a "experiência sensível do político" (conforme também advertia Martinelli), quando a pulsação do instante que se quer devir foi plenamente incorporada à perenidade da arte (adaptando muito sinteticamente as reflexões de Rancière sobre a modernidade).

Vislumbramos certa mudança entre a atitude de combate que distinguiu a posição de Gullar relativamente à poesia, desde sua estreia nos anos 1950, e o que percebemos em sua obra dos últimos livros. Enquanto em seus poemas até a década de 1970 a urgência do movimento da vida, concomitante à negação da forma considerada estática, somava-se tanto à temática política quanto à afirmação da identidade coletiva (o sentimento de irmandade do poeta com o homem comum), como aspectos do mesmo vetor, na obra mais recente há uma interrogação ainda mais constante acerca da infranqueabilidade entre a matéria sensível do real e a poesia. Quando o sujeito lírico indaga por que prefere se deter sobre a morte das frutas em vez de tratar dos graves problemas sociais de sua época, na verdade recoloca a dúvida sobre o destino humano em seus limites: "É a morte que te chama?/É tua própria história/ reduzida ao inventário de escombros/ no avesso do dia/ e não mais a esperança/ de uma vida melhor?/ que se passa, poeta?/ adiaste o futuro?" ("Omissão", Barulhos, 1987). Seria uma constatação, ou mesmo aceitação, da impossibilidade de atingir aquele horizonte utópico com que sonhara na juventude?

O contraste, que sempre suscitou conflito no poeta, entre, de um lado, a manhã, o cheiro de tangerina, a mancha azul, a paisagem solar, e, de outro, a mineralidade do eterno, das constelações, ultimamente, vez por outra, encontrou formulações ríspidas de síntese, talvez resignadas: "todo poema é feito de ar/ apenas", então é mero "barulho".

Se Gullar enfrentou reiteradamente o tema da morte, observamos, entretanto, como tentou pular a barreira entre linguagem e mundo, confessando, afinal, sua impossibilidade. Em "Visita", o sujeito lírico quer conversar com o filho morto no cemitério, único lugar do mundo em que isto seria factível. Embora narrativo, o poema de uma só frase quebrada se lê como uma série de soluços:

no dia de

finados ele foi

ao cemitério

porque era o único

lugar do mundo onde

podia estar

perto do filho mas 


diante daquele
bloco negro
de pedra
impenetrável
entendeu
que nunca mais
poderia alcançá-lo
Então
apanhou do chão um
pedaço amarrotado
de papel escreveu
eu te amo filho
pôs em cima do
mármore sob uma
flor
e saiu
soluçando

(Muitas vozes, 1999 - Gullar, 2008, p.371)

$\mathrm{O}$ visitante reconhece que o papel com o bilhete que deixou sobre o mármore negro terá o mesmo destino da flor. Não parece haver qualquer esperança: a poesia estaria fadada à intransitividade pétrea...

No entanto, a reiterada meditação sobre o lugar excêntrico do poema no mundo continuou a ocupar parte expressiva de sua obra. Seria porventura a suspensão do tempo? Um rumor de frequência inaudível que o poeta capta? Um nada luminoso, a corola que fulgura e faz aparecer o centro opaco das coisas? Essa constatação não traz necessariamente alívio, pois também a morte, em sua poesia, é comparada ao relâmpago, ou a um brilho interno que cada vivente porta, pronto a explodir.

Se "o poema é uma coisa/ que não tem nada dentro", um tipo especial de obra que o poeta e crítico batizou no passado de "não-objeto", ele busca mesmo assim existir, ambiguamente "em alguma parte alguma". O que seria afinal essa linguagem que detona um tipo de efeito imprevisto - alarido, lampejo ou estampido - na zona de contato entre imaginário e real?

Em sua derradeira coletânea, Em alguma parte alguma (Gullar, 2010), procurou algum abrandamento para a contradição que o afligia nas artes plásticas, referência fundamental em sua reflexão poética. No extraordinário "Figura-fundo", começa por sustentar que “a pera pintada é falsa" para afinal concluir que se pode atingir uma "pintura-pera”, tão profundamente verdadeira quanto as frutas naturais. Para falar com Merleau-Ponty (2004, p.36), quando alude a Paul Klee, também Gullar valorizou o encontro com “o coração das coisas”, quando o pintor não se coloca mais à parte para representar o mundo: ambos se criam pela fusão entre quem vê e o que é visto. Então, não existiria separação 
entre "figura" e "fundo", uma vez que a "pera pintada" nasce das palavras densas do poema. Logo, o “objeto" artístico não significaria algo reificado e alheio, pois ocorre uma "transubstanciação do pintor em pintura", quando o artista se converte em "quadro-corpo". A cisão entre palavra e coisa, posto que irredutível, nem sempre pende em desvantagem para a primeira, neste seu trabalho final.

Se a fortuna crítica de Gullar demonstrou de diversas maneiras esse centro de irradiação determinante: "o trepidar do tempo que escorre da torneira" poesia que, tanto através da sonoridade e da imagem, quanto nos possíveis sentidos, se abisma inquieta sobre a transitoriedade humana - também se observa que, depois de bater-se ao longo de toda sua obra com o divórcio entre mundo e arte, no qual esta ansiava por alcançar a consistência das coisas, em mais de um momento deste livro sugere a existência de algo que "fulge", ainda que se assemelhe a "um silêncio/ que o poeta exuma do pó", e que vive ao revés, posto que sem eximir-se da dor. Contudo, este ser híbrido segue existindo, invenção humana para respirar junto com e além da brevidade fugidia, pois "em algum lugar / esplende uma corola”...

\section{Medusa ou mexilhão?}

Jacques Rancière (2007) investigou o duplo sentido do termo resistir, que tanto pode significar algo que perdura (como o monumento e a pedra), quanto pode significar algo ou alguém que se contrapõe ao status quo, à situação do mundo tal como é. ${ }^{7}$ Dessa maneira, haveria um nó que não pode ser abolido, na arte, entre, de um lado, sua autonomia de obra e, de outro, sua potência de transformação, uma vez que ela é tanto forma quanto vibração sensível. No romantismo prolongado, à volta do paradigma da modernidade, que podemos fundar na Revolução Francesa, cada vez mais o objetivo da arte seria sua própria supressão, quando uma nova vida viria, na qual arte, religião, política e economia se integrariam uma à outra. Mas, para que a arte aponte sempre para este devir imaginário, ela deve dilatar e diferir a tensão, mantendo-a irresolvida.

Como paradigmas opostos, poderíamos imaginar dois extremos: de um lado, a vontade de reunir-se ao momento que passa, renegando toda fixação da forma, e proclamando a potência do existir em sua "carnadura", num instante de aparente imediatez; de outro, o empenho em constituir a obra de modo a durar, como "estrutura", contrapondo-se à efemeridade do contemporâneo. Um paralelo nos ocorre quando evocamos os poemas do artista visual belga Marcel Broodthaers (Pense-Bête, 1964), que encarnou essas duas atitudes em animais que ele reputava exemplares: a medusa (ou água viva) representaria o ser que praticamente se amolda e amalgama ao ambiente à sua volta, mimetizando o mar, enquanto o mexilhão ("la moule") seria o bicho que contrasta com seu entorno, protegendo-se graças à sua dura concha (em francês, trocadilho com "le moule", o molde).

A poesia de Gullar exibe a flexibilidade do "mover de nuvem", entre quebras e deslocamentos sintáticos: 
O poema já não quer ser mais poema

quer ser fala

esgarçada e esparsa

mover de nuvem

e sono

que se desenrola azul do joelho

quer ser

um murmúrio

rente à pulsão

estelar

chamada

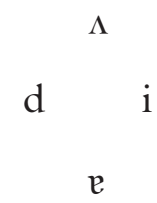

(final de "Fevereiro de 82", Barulhos, 1987 - Gullar, 2008, p.313)

Ao mesmo tempo, conforme se observa, o poeta demonstra alta consciência compositiva na diagramação da página. Tenta, assim, alcançar o que estaria no fundo do signo, como se pudesse torná-lo palpável - entre medusa e mexilhão.

Do ponto de vista da presença, à qual a poesia anseia, na verdade não é nem desejável, nem possível alcançá-la plenamente. A antiarte pode fracassar por completo, limitando-se à vivência fugaz, e aderida a uma realidade que pode ser banal. Da perspectiva do trabalho formal, a fatura depurada impede que o poema se esboroe na linguagem cotidiana, por vezes enrijecida pelo lugar-comum. O coloquialismo, conquista da poética modernista, quando se propõe a conversar com o homem comum, torna-se, com certa frequência, álibi para encurtar a reflexão criativa. Entretanto, ao tentar alcançar, pela arquitetura formal, a perenidade, o tempo vital pode se imobilizar, resultando em tecnicismo e oratória grandiloquente. Gullar tangencia extremos, embora consiga, no geral, não perder nem o fluido que confere maleabilidade nem o molde que permite a forma.

Desde o final dos anos 1950, enquanto nos manifestos da poesia concreta declarava-se que o poema deveria ser um objeto, Gullar contrapunha a concepção de obra artística como um não-objeto, contradizendo o programa assumido pelos seus coetâneos de vanguarda. ${ }^{8}$ Ora, as duas tendências são, em sua origem, modernas, explicitamente descendentes da estética construtiva, que acreditava na consistência da fatura formal, em prol de "uma integração funcional da arte na sociedade", com um sentido de "intervenção" "de natureza didática", "útil" 
(ao contrário do surrealismo, condenado por eles, nos anos 1950 e 1960, como "mágico", "místico" e "maudit", junto com quaisquer tendências "românticas" ou "expressionistas") (ver Brito, 1999, p.15). Na verdade, o trabalho de cada uma delas (concretos e neoconcretos) originou-se de fontes distintas e, embora tenham se aproximado em certa época, a atração pelo racionalismo tecnológico da Escola de Ulm apenas tangenciou de leve Gullar, uma vez que no início da sua trajetória, a vontade destrutiva impunha-se mais intensa. Por outro lado, num dado momento, o construtivismo russo fascinou a todos, ao menos em relação a alguns de seus princípios materialistas e revolucionários, e à sua adesão à sociedade urbana e industrial.

Todavia, o "retorno das intenções expressivas ao centro do trabalho da arte" (Brito, 1999, p.58), nos neoconcretos, concorreu para que, muito depressa, também despontassem dúvidas sobre o dogmatismo ortodoxo do "plano-piloto". Logo, uma inquirição pertinaz sobre os limites da obra se instala na produção poética e ensaística de Gullar.

Assim falando, parecemos ignorar a tradição moderna da poesia brasileira como fonte de inspiração para Gullar (notadamente o espírito livre e iconoclasta dos modernistas de primeira hora e a "arquitetura funcional" de João Cabral). Para não nos alongarmos na descrição das influências literárias nele inscritas, mencionamos apenas a sua batalha para reivindicar o legado de Oswald de Andrade, do qual se julgava o "legítimo" sucessor. Mas, como o poeta modernista contribuiu para o estilo de Gullar? Seria o caso de averiguar o que exatamente ele deglutiu como herança do nosso antropófago. Possivelmente, encantava-o o viço, a inovação, mas também a intimidade com a terra brasileira, a concretude do "sabor de capim verdade" (Gullar, 2007, p.22) que vai se refletir em mais de um aspecto de sua poética.

Para concluir, a pergunta sobre o sentido da poesia, que Gullar explicita em tantos poemas, não o conduz até o extremo da destruição da arte, a qual repropõe inúmeras vezes. Revive o dilema da resistência poética como emblema inescapável, mesmo quando tenha anteriormente anunciado exatamente o contrário em suas experimentações com palavras libertas da página do livro, que pediam a participação do leitor para operarem seu possível sentido (como o "Poema enterrado", 1959).

Pois o poema movimenta-se na página de acordo com andamentos diversos, acoplados e paradoxais: quer como brusco impulso, que se assemelha ao jorro ou salto, quer como ginástica serial, que se posiciona em estruturas variáveis. Ou ainda, como a ação violenta dosol do meio-dia, a estiolar as frutas, e à qual se contrapõe a escora da memória e do desejo para firmar-se no instante - enquanto o poeta ausculta o pulso de estrelas e homens no curso de noites e dias. 
1 O enciclopédico volume de Michael Hamburger (2007) trata dessa tendência com argúcia extraordinária.

2 Este artigo integra um estudo maior sobre a poesia brasileira a partir da década de 1960 . Trata-se de capítulo da tese de livre-docência Poesia em risco (itinerários a partir dos anos 60) (de 2011), aqui revisado e ampliado. Algumas partes do texto foram anteriormente publicadas. Remeto à Revista Maracanan, n.11 (UERJ, 2014) e ao libreto sobre Ferreira Gullar da série "Fronteiras do pensamento" (2015).

3 Por exemplo, de acordo com Brito (1999): tirar a pintura do espaço bidimensional e levá-la para o espaço multidimensional (como estava tentando Lygia Clark); corporificar e construir o poema em objeto espacial (como fez Gullar com seu "Poema enterrado"; ou ainda programar-se para agir como modelo de construção social, de modo a coletivizar suas produções e ter uma ação educativa - como se o artista fosse sobretudo um informador visual - opondo-se a tendências oníricas, subjetivas, surrealistas. Também o conceito de um espectador participante é gerado destas primeiras experiências artísticas.

4 Confira-se a bela análise desse poema realizada por Alcides Villaça (1998, p.94-5), em "Gullar: a luz e seus avessos", na qual o crítico distingue "os cinco primeiros versos", os quais "oferecem-nos a visão descritiva das frutas" dos "cinco restantes" que "elaboram liricamente o material apresentado. Duas naturezas se oferecem, em dois tempos destacados: a reconhecida pelos olhos (com formas, cores, planos, perspectiva) e a trabalhada pelas impressões (por meio de metáforas, sinestesias e paradoxos). Uma 'natureza morta', picturalmente imobilizada, torna-se convulsa e sugestiva em outra que a traduz. Como pano de fundo à apresentação das frutas atua, no entanto, 'o mar atrás', signo da inquietação do que está 'atrás' não como cenário, mas como perturbadora infinitude. Os elementos plásticos da primeira cena temporalizam-se no segundo momento: a 'mesa no domingo' torna-se 'o centro do dia'. A 'faixa amarela' desdobra-se em 'fogueira sólida' e contrasta com o insólito 'fogo escuro', 'que não cabe hoje nas frutas'. Por que não cabe? Porque as frutas estão no auge do viço (maçãs vermelhas, bananas amarelas), e a ameaça mortal do 'escuro' diz respeito ao fogo destrutivo, que ainda não surgiu".

5 Meschonnic (2006, p.64) dirá que a linguagem poética, quando bem praticada, é oralidade. Isto é, ela consegue imprimir o corpo vivo na linguagem. Cito: “O máximo possível do corpo e de sua energia. Como ritmo. O ritmo como forma-sujeito". A voz do poeta se faz sentir em seu timbre particular. Como se o dizer pudesse tangenciar um fazer, sendo, através da sonoridade e da imagem, mais concreto.

6 No entanto, ao tentar cumprir essa proeza, conclui da sua impossibilidade. Cito seu depoimento: "imaginei que poderia vomitar, em escrita automática (automatisme psychique), sem ordem discursiva, a massa da experiência vivida - lançar o passado em golfadas sobre o papel e, a partir desse magma, construir o poema que encerraria a minha aventura biográfica e literária.”... "logo me pus em frente à máquina de escrever: mas o 'vômito' não vinha e não sabia como provocá-lo. Como meter o dedo na garganta da linguagem se a linguagem não tem garganta?” E, afinal, conclui: "O poema deve começar antes de mim, pensei, começar antes do verbo" (Gullar, 2001, p.viii).

7 Sobre essa segunda acepção, ver o ensaio "Poesia resistência", de Alfredo Bosi (1977), constante em $O$ ser e o tempo da poesia.

8 Acerca das divergências entre concretos e neoconcretos recomenda-se a leitura do livro clássico, já citado, de Ronaldo Brito (1985, reimpr. 1999, p.9). Cito: "Esta a verda- 
de neoconcreta: ter sido o vértice da consciência construtiva brasileira - produtor das formulações talvez mais sofisticadas nesse sentido - e simultaneamente o agente de sua crise, abrindo caminho para sua superação no processo de produção de arte local" [...] "E nesse sentido ele foi um precursor das tendências dominantes nos anos 60 que representavam um esforço para abolir a distância entre arte e vida" (ibidem, p.80) - as oposições são de ordem filosófica (um tenderia à Gestalt e ao positivismo, e outro à fenomenologia; um tenderia ao matemático e outro à intuição expressiva, um pensaria o tempo de forma sincrônica, o outro tenderia à duração).

\section{Referências}

BOSI, A. Poesia e resistência. In: O ser e o tempo da poesia. São Paulo: Cultrix; Edusp, 1977.

. Roteiro do poeta Ferreira Gullar. In: Os melhores poemas de Ferreira Gullar. Sel. A. Bosi. São Paulo: Global, 1983.

ção ampliada ]

A. Céu, inferno. 3.ed. São Paulo: Livraria Duas Cidades; Ed. 34, 2003. [edi-

BRITO, R. Neoconcretismo - vértice e ruptura do projeto construtivo brasileiro. Rio de Janeiro: MEC/Secretaria da Cultura/Funarte, 1985.

. Neoconcretismo - vértice e ruptura do projeto construtivo brasileiro. São Paulo: CosacNaify, 1999.

GULLAR, F. Reinvenção da poesia. In: _..Indagações de hoje. Rio de Janeiro: José Olympio, 1989.

. Poema sujo. Rio de Janeiro: José Olympio, 2001.

. Experiência neoconcreta. São Paulo: Cosac Naify, 2007.

. Poesia completa, teatro e prosa. Org. e prefácio Antonio Carlos Secchin. Rio de Janeiro: Nova Aguilar, 2008.

. Em alguma parte alguma. Rio de Janeiro: José Olympio, 2010.

HAmbUrger, M. A verdade da poesia. Trad. Alípio Correia de Franca Neto. São Paulo: Cosac Naify, 2007.

LAFETÁ, J. L. Traduzir-se. In: ZILIO, C.; LEITE, L. C.; LAFETÁ, J. L. O nacionale o popular na cultura brasileira. São Paulo: Brasiliense, 1982.

. Dois pobres, duas medidas. In: SCHWARZ, R. (Org.) Os pobres na literatura brasileira. São Paulo: Brasiliense, 1983.

. A dimensão da noite. Org. A. Arnoni Prado. São Paulo: Duas Cidades; Ed. 34, 2004. [republicação de $O$ nacional e o popular na cultura brasileira]

MARTINELLI, L. Ferreira Gullar e o tempo do poema. Revista Inimigo Rumor, Rio de Janeiro, n.3, 1997.

MERLEAU-PONTY, M. O olho e o espirito. Trad. Paulo Neves e Maria Ermantina Galvão Gomes. São Paulo: Cosac Naify, 2004.

MESCHONNIC, H. Linguagem, ritmo e vida. Trad. Cristiano Florentino. Belo Horizonte: FALE/UFMG, 2006. 
RANCIÈRE, J. Será que a arte resiste a alguma coisa? In: LINS, D. (Org.) Nietszche/ Deleuze: arte, resistência. Trad. Mônica Costa. Rio de Janeiro e Fortaleza: Forense Universitária; FCET, 2007.

VILLAÇA, A. A poesia de Ferreira Gullar. São Paulo. 1984 Tese (Doutorado) - Faculdade de Filosofia, Letras e Ciências Humanas, Universidade de São Paulo. São Paulo, 1984.

. Gullar: a luz e seus avessos. Ferreira Gullar. Cadernos de Literatura Brasileira. São Paulo, Instituto Moreira Salles, n.6, set. 1998.

Em torno do Poema sujo. In: GULLAR, F. Poesia completa, teatro e prosa. Org. e pref. Antonio Carlos Secchin. Rio de Janeiro: Nova Aguilar, 2008.

RESUMO - O presente estudo aborda dois aspectos interligados da trajetória de Ferreira Gullar: ora o questionamento em relação à poesia, ora a interrogação sobre o tempo. Desde o início de sua obra, o hiato entre mundo e palavra é constantemente problematizado, assim como a passagem da vida, em sua ocorrência fugaz, para a matéria perene do poema. Esse conflito manifesta-se não apenas na temática, mas também na formalização mesma do poema. Por vezes, a tensão resultante entre arte e vida leva à insatisfação do poeta contra suas próprias realizações. Depois de percorrer diferentes momentos da produção de Gullar, e tendo comentado como o Poema sujo tenta aprofundar essa reflexão, conclui-se que houve uma relativa transformação nos últimos livros do poeta, quando ele parece se aproximar de uma tentativa de conciliação entre a composição artística e a transitoriedade do tempo presente.

PALAVRAS-CHAVE: Ferreira Gullar, Poesia brasileira, Tempo, Representação poética.

ABSTRACT -This study tackles two interrelated aspects of Ferreira Gullar's trajectory: his questionings regarding poetry and his questionings regarding time. From even his earliest works, the gap between world and word is constantly addressed - as is the passing of life, in its fleeting occurrence, into the perennial matter of the poem. This conflict manifests itself not only in his chosen themes, but also in the formalization of the poem itself. At times, the resulting tension between art and life leads to the poet's dissatisfaction with his own achievements. After traversing different moments of Gullar's production, and having commented on how Poema Sujo [Dirty Poem] attempts to deepen this reflection, we conclude that a relative transformation occurred in the poet's last books, when he seems closer to seeking conciliation between artistic composition and the transience of the present time.

KEYWORDS: Ferreira Gullar, Brazilian poetry, Time, Poetic representation.

Viviana Bosi é professora livre-docente do Departamento de Teoria Literária e Literatura Comparada, Faculdade de Filosofia, Letras e Ciências Humanas, USP.

@ - vivianab@usp.br

Recebido em 20.2.2017 e aceito em 8.3.2017.

${ }^{\text {I }}$ Faculdade de Filosofia, Letras e Ciências Humanas, Universidade de São Paulo, São Paulo / São Paulo, Brasil. 